UDC 378.1

\title{
SYSTEM OF HIGHER EDUCATION IN SWITZERLAND
}

\author{
M. S. Dushenok \\ Kyiv, National technical university of Ukraine "Kyiv polytechnic institute" \\ marynadushenok@gmail.com
}

\begin{abstract}
The article highlights higher education in Switzerland as one of the high quality in the world. It collaborates and is funded by private sector. Swiss higher education follows the three-tiered structure of Bachelor's, Master's and doctoral studies (with $\mathrm{PhD}$ titles being reserved to federal institutes of technology and cantonal universities). All the universities are divided into federal institutes of technology (namely Swiss Federal Institute of Technology and Ecole Polytechnique Fédérale de Lausanne), cantonal universities (there are ten of them), universities of teacher education (comprising fourteen UTEs and four other teacher training institutions such as the Swiss Federal Institute for Vocational Education and Training and the Swiss Federal Institute of Sports Magglingen) and universities of applied sciences (providing 300 degree programmes). In Switzerland traditional institutions are centered on basic research, while others are based on applied research. Courses at the graduate level are taught in English. Structure of the studies depends on faculty involved. For instance, almost all disciplines require 8-9 semesters to graduate. The system of higher education in Switzerland is deeply integrated into European one. It provides universities with range of opportunities to collaborate with other outstanding universities all over the world. Also the benefits of such system of higher education are described.
\end{abstract}

Key words: higher education, university, Switzerland, institute, research.

Introduction. Quality of education is of primary importance for successful and developed countries. Ukraine also declares its intention to be one of them. Therefore, education in Ukraine faces new problems to enhance national educational system and become the country with effective scientific background. In order to justify our expectation, we should align with reputable countries and educational institutions. Switzerland is well-known country with outstanding level of education and science.

Therefore, the aim of our study is to analyze with the system of higher education in Switzerland.

Switzerland is situated in Western and Central Europe and it shares boarders with Italy, France, Germany, Austria and Liechtenstein. There are now approximately 8 million people living in Switzerland, speaking four official languages: German, French, Italian and Romansh [9]. Switzerland is a small country with great diversity: languages, cultures, economic branches, and different landscapes all co-exist in this tiny area. At the same time, however, Switzerland is a country that is opened to the rest of the world: over $20 \%$ of the population holds a foreign passport, the Swiss economy is heavily export-driven and several international organisations are based here. The standard of living is high [3, p.7].

The Swiss system of education is divided into four levels: primary, secondary, tertiary and quaternary. Primary and a part of the secondary level (secondary level I) are compulsory. Following these parts, Swiss students are able to take one of two directions: either leading to a sound general education or to preparation to specific trade or profession. Than education continues with higher education level (see Fig. 1) [5, p.12] .

System of higher education originates from University of Basel (was founded in 1460). Its history goes back over 550 years and the University is the oldest in Switzerland. It has an international reputation of outstanding achievements in research and teaching [8].

Nowadays, the Swiss higher education landscape (tertiary level) is comprised of a comprehensive and diverse range of high-quality federal institutes of technology, cantonal universities (both are traditional institutions), universities of teacher education and universities of applied sciences. Overall number of universities in Switzerland is 19.

Traditional institutions are centred on basic research, while others are based on applied research. 

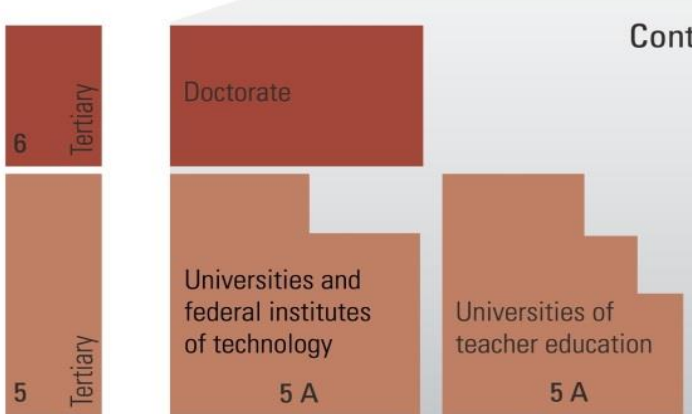

Continuing education

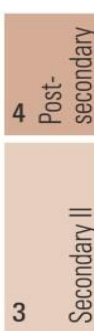

4 A Adult matura school

4 B Vocational training (second career training)
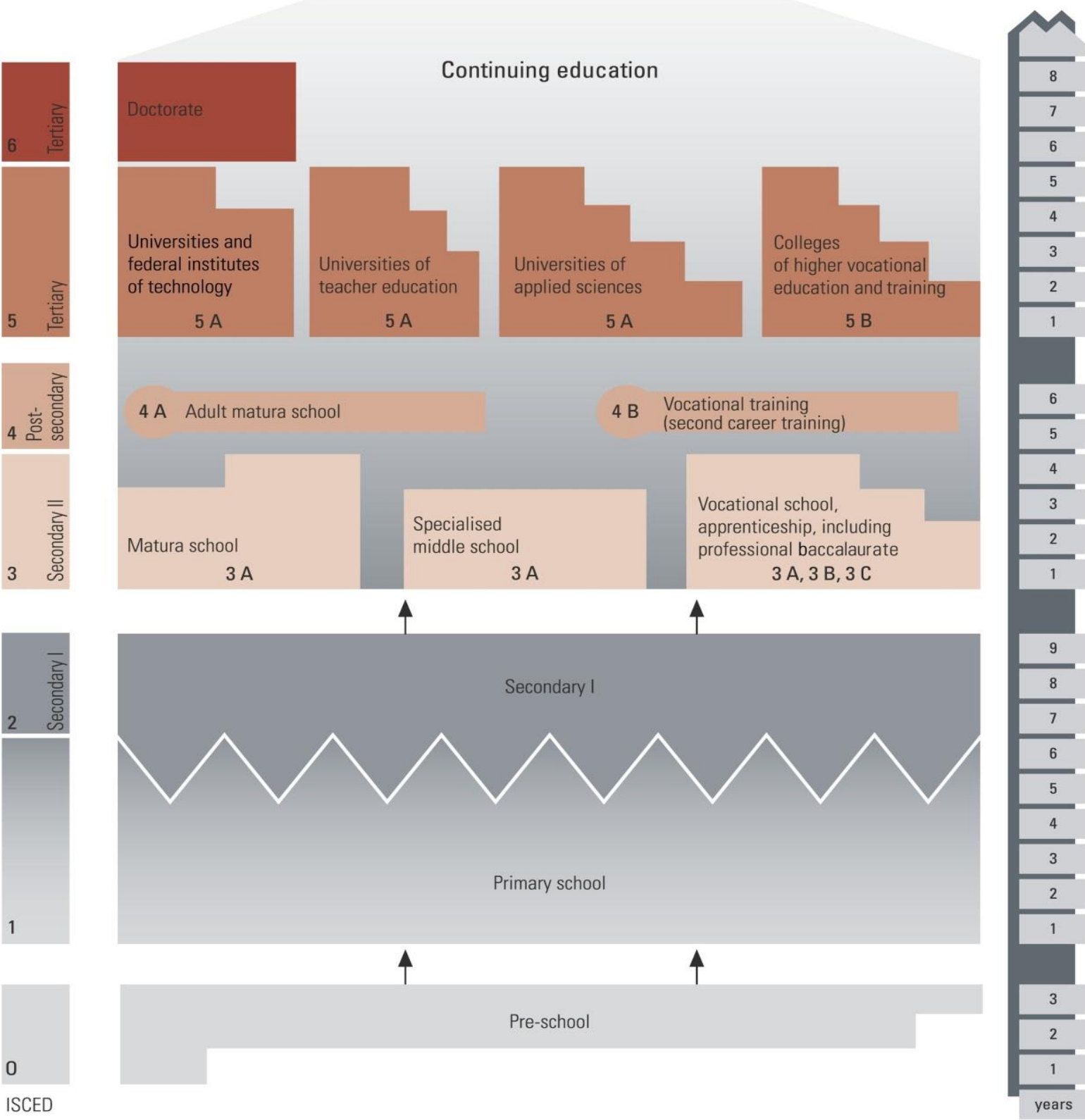

Figure 1: Diagram of the Swiss Education System

Tertiary educational level follows the three-tiered structure of Bachelor's, Master's and doctoral studies (with $\mathrm{PhD}$ titles being reserved to federal institutes of technology and cantonal universities). All higher education institutions are active in teaching, research, continuing education and training.

Federal Institutes of technology. There are two federal institutes of technology in Switzerland. They are located in German-speaking Zurich and French-speaking Lausanne.

The sixteen departments of Swiss Federal Institute of Technology (or ETH - Eidgnoessiche Technische Hochschule) offer Bachelor's, Master's and doctoral programmes in natural sciences and engineering. The language of instruction in the Bachelor's programmes is German, which is one of four official languages in the country, whereas courses at the graduate level are taught in English. All degree programmes provide a solid scientific base, preparing ETH graduates to apply their knowledge and skills in business, industry or the public sector, as scientists or entrepreneurs [2].

The Ecole Polytechnique Fédérale de Lausanne (EPFL) was founded in 1853. Since that time EPEL evolved into a strategic centre of innovation in Switzerland and an internationally recognized institution. During its history EPEL has kept revamping, evolving its programmes or 
creating new curricula to anticipate technological and scientific developments. As well as ETH, EPEL offers Bachelor's, Master's and doctoral programmes. In addition, the university has Science Park. It highlights EPEL's technology transfer, as 100 companies are hosted there [1].

Cantonal Universities. There are 10 Cantonal universities in Switzerland. They are located in German-speaking (Basel, Bern, Lucerne, St Gallen and Zurich), French-speaking (The Universities of Geneva, Lausanne and Neuchatel) and Italian-speaking (Lugano) parts; University at Fribourg is bilingual (German and French languages). Most of the universities offer majors in social sciences and law, natural sciences and mathematics, and the humanities. Half of the Cantonal universities have their own faculty of medicine. Almost all disciplines require 8-9 semesters to graduate $\left(9^{\text {th }}\right.$ semester is added for the diploma or licentiate thesis, but medicine, that involves the longest study period). Structure of the studies depends on faculty involved. Nevertheless, generally students commence with a basic course of studies ending with an exam leading to a diploma or licentiate course during which specialization begins [5, pp.16-17].

Universities of Teacher Education (UTEs). The training of teaching staff is also provided by Tertiary educational level. This type of universities was established in 1990s, due to a comprehensive reform of teacher education.

Swiss-wide, there are 14 UTEs to choose from. Four other teacher training institutions are embedded in other types of higher education institution. In addition, there are two federal institutions that train teachers: the Swiss Federal Institute for Vocational Education and Training (SFIVET) and the Swiss Federal Institute of Sports Magglingen (EHSM) [4, p.18].

Having practice-oriented degree programmes and due to its research which is oriented towards occupational fields, UTEs are classed as universities of applied sciences. Nonetheless, they are governed differently. The remit of the universities of teacher education comprises initial education and training and continuing education and training, application-oriented research and development, and services for third parties [7].

Such components as scientific, teaching-specific, educational science practical training and professional qualifications are provided by the degree programmes in teacher education and training. They combine practical work, theory, research and teaching.

According to the Bologna Declaration, teacher education and training is realized within two-tier model (Bachelor's and Master's degree programmes). Selected degree programme influences duration of the studies. Being graduated, teaching staff receive a qualification for the specific educational level, or professional qualification in the field of special needs education, as well as a Bachelor's or Master's degree. (Exception: Teachers for Baccalaureate schools only receive a teaching qualification. The Master's degree is obtained through their scientific study) [7].

Universities of Applied Science (UAS). There are seven regional public universities of applied science (set up in 1990s) and two approved by the Federal Council private UAS (founded in 2005 and 2008). Universities of applied science develop the ability to apply scientific methodologies and knowledge; most prospective of the candidates for UAS studies hold an uppersecondary level Federal VET Diploma. This type of universities is focused on applied development and research, therefore the universities are considered to be drivers of innovation [3, p.18].

Still not all UASs offer the full range of courses, the courses on offer include: applied linguistics; applied psychology; architecture; business and services; chemistry; construction and planning; design; engineering; agriculture and forestry; health; information technology; life sciences; music; physical education; social work; theatre and other artistic disciplines [4, p.18].

300 degree programmes are available at UAS. About 220 of the programmes are at Bachelor's degree level which lasts for three years of full-time study or four to five years of partstudy time. Master's degree generally require three semesters. Master's degree programmes at UAS focus on research and lead to more advanced professional qualification. Although universities of applied science offer a wide range of continuing education and training courses, including advanced studies programmes leading to the Certificate of Advanced Studies (CAS), Diploma of Advanced Studies (DAS) or Master of Advanced Studies (MAS) as they are to fulfil labour market needs [3, p.18]. 
Swiss research, development and innovation. The R\&D success is guaranteed due to the close link between the private sector and the universities. Being an important link in the innovation chain, this cooperation provides an opportunity to transfer knowledge from the research laboratory to the market.

Swiss universities have the preserve of basic research due to the traditional distribution of private and public sector roles. Private sector is the main driving power $(75 \%$ of all R\&D expenditure) of applied research and the development of research findings into marketable products and services. The major share of public funding for basic research is channelled to Swiss Cantonal universities and Federal institutes of technology (ETH and EPFL) likewise to four specialized research institutes within EHT domain:

1) the Paul Scherrer Institute (research centre for natural sciences and engineering);

2) the Swiss Federal Laboratories for Materials Science and Technology;

3) the Swiss Federal Institute for Forest, Snow and Landscape Research;

4) the Swiss Federal Institute of Aquatic Science and Technology (which focuses on concepts and technologies designed to ensure sustainable water resources and the treatment of wastewater) [6].

Swiss integration into national knowledge network. As Switzerland is a small country, it is extremely important to be involved and integrated into the European and global knowledge networks. Still Federal Council established the following priorities in international cooperation:

- participation in the development of the European higher education and research area;

- further development of cross-border cooperation with neighbouring regions;

- support for the international scientific and technological cooperation of Swiss tertiary education institutes [5, p.25].

For first target realization active participation in European and global research programmes is obligatory. Therefore, since 1992 Switzerland has been participating in the European Union (EU) frame network. It is also represented in numerous other European and international institutions and programmes such as the European Organisation for Nuclear Research, the Human Frontier Science Programme HFSP, the European initiative EUREKA and the European Space Agency ESA.

The second priority suggests implementation of the Bologna Declaration and participation in the EU programmes for education, professional training and youth to improve mobility of researchers and students. Therefore, two stage of education was implemented (three years of basic studies gaining Bachelor's degree and one and a half or two years to obtain Master's degree). This system is completed by the doctorate $(\mathrm{PhD})[5, \mathrm{p} .26]$.

As for third point, the Bologna Declaration in Switzerland is underway of its implementation. Federal institutes of technology have already applied the new structure in all their courses. The Cantonal universities have also adapted the majority of their courses.

Conclusions. System of higher education in Switzerland has primary, secondary, tertiary and quaternary educational levels. Having completed compulsory part of education, students can choose one of two directions: either leading to a sound general education or to preparation to specific trade or profession.

Taking into consideration tertiary level of education, we can summarise that all Swiss universities are divided into federal institutes of technology, cantonal universities, universities of teacher education and universities of applied sciences. All the higher educational level institutions have three-tiered structure (Bachelor's, Master's and doctoral programmes in natural sciences and engineering).

Educational system in Switzerland is integrated into European system of education. It provides universities with range of opportunities to collaborate with other outstanding universities all over Europe and world. In addition, the Universities are closely connected to the private sector. It provides additional founding and, as a result, research stimulation.

All-in-all, the article is to serve as a basis for future research and analysis of Swiss higher education system. 


\section{REFERENCES}

1. Ecole Polytechnique Fédérale de Lausanne (EPFL). Retrieved from http://www.studyinginswitzerland.ch/epfl/university-description?id=12

2. Higher education and research in Switzerland. Retrieved from https://www.eda.admin.ch/content/dam/countries/countries-ontent/canada/en/Campus_Switzerland_2011-1-pdf
3. Higher
education
and research
in Switzerland.
Retrieved
from

http://edudoc.ch/record/109804/files/campus-switzerland-e.pdf

4. Higher education and research in Switzerland. Retrieved from http://edudoc.

ch/record/116864/files/HE_en.pdf

5. Higher education in Switzerland [Electronic resource]. Retrieved from

http://www.ond.vlaanderen.be/hogeronderwijs/bologna/links/documents/Higher_Education_in_Switzerland.pdf

6. Science and technology [Electronic resource]. Retrieved from https://www.eda.admin.ch/content/dam/countries/countries-content/south-africa/en/ SSAJRP-Booklet_EN.pdf

7. Teacher education and training [Electronic resource]. Retrieved from https://swisseducation. educa.ch/en/teacher-education-and-training

8. University of Basel [Electronic resource]. Retrieved from https://www.unibas.ch/en/University/ AboutUniversity.html

9. Welcome to Switzerland [Electronic resource]. $\quad$ Retrieved from

http://www.studyinginswitzerland.ch/country-welcome-to-switzerland.htm

М. С. Душенок. Система вищої освіти в Швейцарії.

В статті розглядається система вищої освіти в Швейцарії. Університети співпрацюють 3 приватними підприємцями. Фінансування вищої освіти в Швейцарії відбувається переважно за рахунок приватного сектору. В освітній системі, яку ми розглянули, $є$ трирівнева структура: бакалавр, магістр i докторант (PhD). Університети поділяються на технологічні, кантоніальні, університети для підготовки вчителів та університети прикладних наук. Програма навчання залежить від університету. Майже на всіх напрямках підготовки навчаються 8-9 семестрів. Післядипломна освіта викладається виключно англійською мовою. Система вищої освіти в Швейцарії глибоко інтегрована в європейську. Вона надає університетам можливості співпрацювати 3 іншими провідними університетами по всьому світу. Також в статті нами були зазначені переваги такої системи вищої освіти.

Ключові слова: вища освіта, університет, Швейцарія, інститут, дослідження.

М. С. Душенок. Система высшего образования в Швейцарии.

В статье рассматривается система высшего образования в Швейцарии. Университеты сотрудничают с частными предпринимателями. Финансирование высшего образования в Швейцарии происходит в основном за счет частного сектора. Образовательная система, которую мы рассмотрели, имеет трехуровневую структуру: бакалавр, магистр и докторант $(\mathrm{PhD})$. Университеты делятся на технологические, кантональные, университеты для подготовки учителей и университеты прикладных наук. Программа обучения зависит от типа университета. Обучения на всех видах подготовки длится 8-9 семестров. Последипломное образование проходит исключительно на английском языке. Система высшего образования в Швейцарии глубоко интегрирована в европейскую. Она предоставляет университетам возможности сотрудничать с другими ведущими университетами по всему миру. Также в статье нами были отмечены преимущества такой системы высшего образования.

Ключевые слова: высшее образование, университет, Швейцария, институт, исследование. 